資料

\title{
特殊栄養食品制度から栄養表示基準制度への変遷
}

一一強化食品加ら栄盖表示食品

$$
\text { 中村尚夫*・吉澤みな子* }
$$

The Japanese Institutional Changes from Special Nutritious

Foods to Nutritional Labeling Standard

-From Enriched Foods to Nutritional Labeling Foods-

$$
\begin{aligned}
& \text { Hisao NAKAMURA* and Minako YoshizawA* } \\
& \text { * Department of Nutrition, Koshien University, } \\
& \text { 10-1 Momizigaoka, Takarazuka, Hyogo } 665
\end{aligned}
$$

平成 7 年 5 月 24 日, 食品衛生法及び栄養改善法の一 部を改正する法律（第 101 号）により, 栄養改善法（昭 和 27 年法律第 248 号) の第十二条が改正された. 栄養表 示基準制度が創設されたのに伴い，栄養成分の補給が出 来る旨の標示の許可制度 (強化食品制度) が廃止され, 特殊栄養食品の名称も廃止され, 特別用途食品に係る表
示の方法の改正が行われた1) (表 1 参照)。ここに，食品 表示の改正点を紹介する. この法律は平成 8 年 5 月 24 日に施行された。

\begin{tabular}{|c|c|}
\hline 昭和 27 年 7 月 4 日 & 栄養改善法案可決成立 \\
\hline 8 月 30 日 & 栄養改善法施行規則厚生省令第 37 号 \\
\hline 8 月 31 日 & 栄養改善法公布法律第 248 号 \\
\hline 46 年 4 月 8 日 & 特殊栄養食品の標示許可衛発第 222 号 \\
\hline 平成 3 年 7 月 11 日 & $\begin{array}{l}\text { 栄羔改善法施行規則の一部改正（強化 } \\
\text { 栄養素追加, 特定保健用食品の創設) } \\
\text { 厚生省令第 } 41 \text { 号 }\end{array}$ \\
\hline 7 年 5 月 24 日 & $\begin{array}{l}\text { 食品衛生法及び栄養改善法の一部を } \\
\text { 改正する法律, 法律第 } 101 \text { 号 }\end{array}$ \\
\hline 7 年 5 月 24 日 & $\begin{array}{l}\text { 食品衛生法及び栄養改善法の一部を } \\
\text { 改正する法律の施行（特殊栄養食品 } \\
\text { の名称廃止, 強化食品廃止, 栄養表示 } \\
\text { 基準制度へ信設) 衛食第 } 105 \text { 号 }\end{array}$ \\
\hline 8 年 5 月 20 日 & 栄養表示基準を定めた件厚生省告示第 146 号 \\
\hline 5月 24 日 & 同施行 \\
\hline
\end{tabular}

\section{1. 強化食品の変遷}

栄養成分の補給が出来る旨の標示をする食品（以下強

表 1 栄養改善法関連年表

* 甲子園大学（宁665 宝塚市紅葉ガ丘 10-1） 
化食品）は，栄養改善法施行規則（昭和 27 年厚生省令第 37 号以後 18 回部分改正, 以下「規則」という）第八条第 1 項の第五号に規定されていた2).

特殊栄養食品の標示許可については，昭和 46 年衛発 第 222 号厚生省公衆衛生局長通知（以後 6 回改正）で取 扱い要領が改正された ${ }^{33}$ ．強化食品については，規則第 八条第 1 項第五号に示されている上うに，強化対象食品 として昭和 48 年以降も許可対象であったものは，米，押 麦, 小麦粉, 食パン, ゆでめん, 乾めん（マカロ二, ス パゲティを含む)，即席めん，味啗，マーガリン，魚肉八 ム・ソーセージの 10 品目であった。昭和 48 年以降, しょうゅ, 清凉歕料水, 濃縮果汁, シャム・ママレー ト・はちみつ，カレールウ・ハヤシルウ，粉末欺料，菓 子、離乳食等が除外された (表 2 参照). 強化食品の標示 許可の対象となる栄養成分については，表 2 に示すよう に，强化対象食品により添加栄養素が定められており， ビタミン $\mathrm{A}, \mathrm{B}_{1}, \mathrm{~B}_{2}, \mathrm{Ca}$ 、リジンの 5 栄養素であった。 た だし昭和 48 年以降除外された食品には，ビタミン $\mathrm{C}, \mathrm{Fe}$ の添加が認められていた。

規則の一部が，平成 3 年 7 月 11 日厚生省令第 41 号を
あって改正され4), 食品の標示許可の対象となる栄養成 分が、ビタミン $\mathrm{A}, \mathrm{B}_{1}, \mathrm{~B}_{2}, \mathrm{Ca}$, リジンにビタミン $\mathrm{C}, \mathrm{D}$, $\mathrm{Fe}$ のつが加わり，8 栄養成分となった.

前文にあるように，この強化食品制度は，平成 7 年法 律改正に上り特殊栄養食品の名称廃止とともに廃止と なっだ（図 1 参照)。なお，この法律は，平成 8 年 5 月 24 日から施行されることとなったか，平成 9 年 5 月 29 日までは経過措置として，引き続き，改正前の規定に適 合する標示がされている限り，新栄養改善法（平成 7 年 法律第 101 号) 第十七条第 1 項の栄養標示基準に適合す る標示がされているすのとみなされる.

\section{2. 機能性食品から特定保健用食品人}

機能性食品とは, 食品の三次機能としての生体調節機 能（生体防御，体調リズムの調節，老化㧕制，疾患の防 止, 疾病の回復）をむつ食品)，すなわち，「食品成分の 6つ生体防御，体調りズム調節，疾病の防止と回復等に 係る体調調節機能を，生体に対して十分に発現できるよ うに設計し，加工された食品」，あるいは，「食品の品質 变換操作により得られた機能性成分を活用して，生体に

表 2 強化食品と強化栄養素

\begin{tabular}{lllllllllll}
\hline \hline & & & & & & & & & \\
\hline
\end{tabular}

注：※（強化食品）は昭和 48 年度以降許可対象から除外された品 目である。 


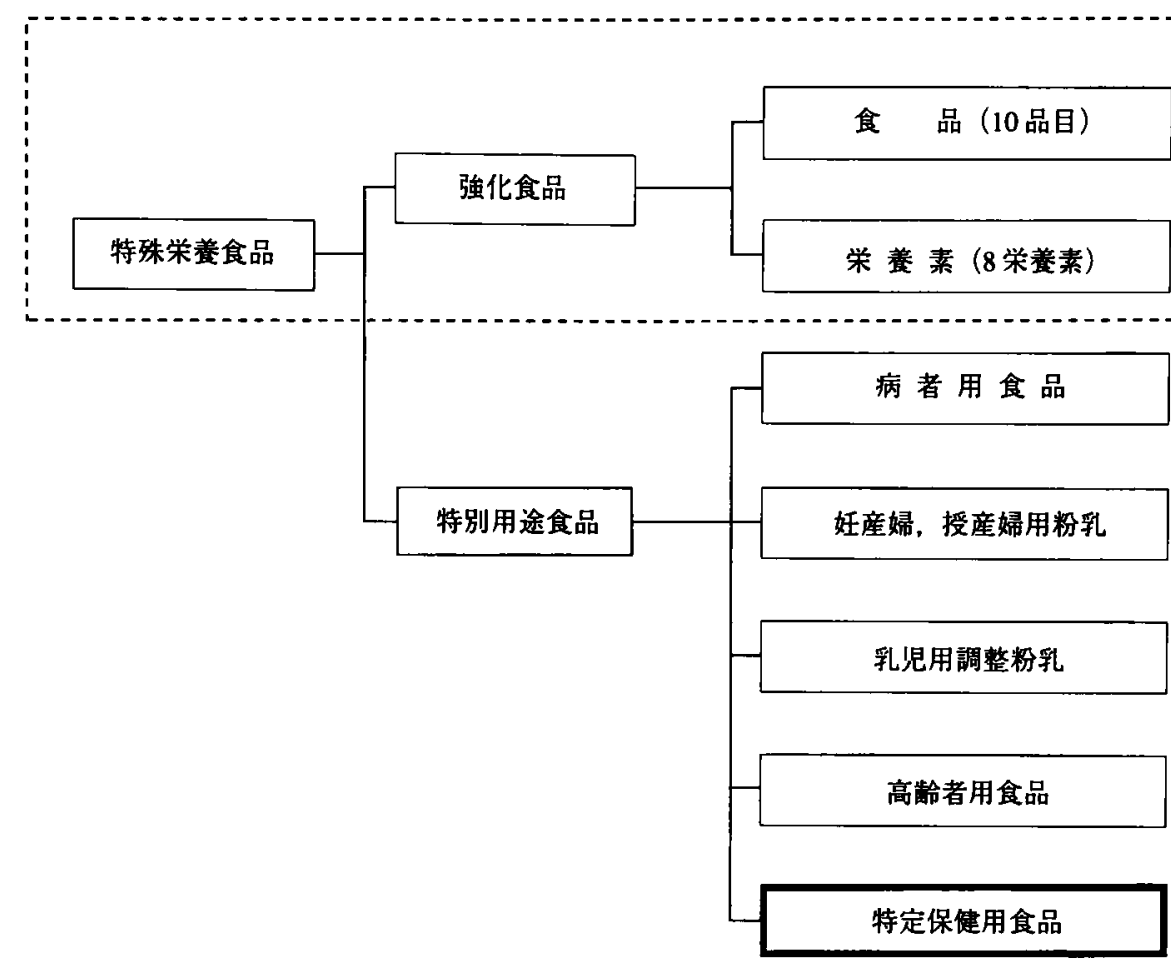

注）特定保健用食品以外の特殊栄盖食品にはそれぞれ個別に許可の規格基準が 定められていた。点線枠内は，1996年 5 月 24 日以降糜止された。

図 1 特殊栄養食品制度加ら特別用途食品制度人

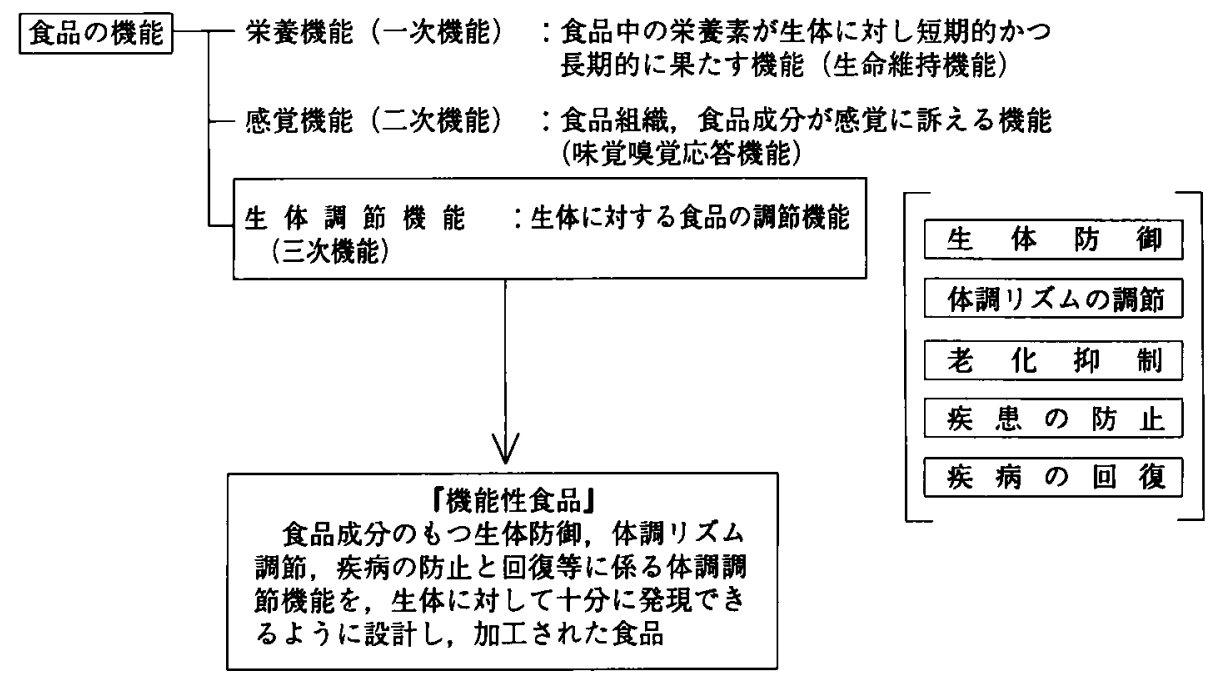

図 2 『機能性食品』の概念 
对し期待された勃果を十分に発現できるように設計され た，日常的に摄取する食品」と定義された（図 2 参照).

文部省は，昭和 59 年より文部省科学研究費補助金に よる特定研究「食品機能の系統的解析」, 昭和 63 年上り 文部省重点領域研究「食品の生体調節機能の解析」, さら に平成 4 年重点領域研究「機能性食品の解析と分子設 計」により，機能性食品研究をすすめだ．

機能性食品の法制化を検討してきた厚生省は，平成 3

\section{表 3 特定保健用食品の許可件数の推移}

\begin{tabular}{rlr}
\hline \hline 1. 平成 5 年 6 月 1 日 & 2 品目 \\
2. & 平成 5 年 10 月 1 日 & 11 品目 \\
3. & 平成 6 年 4 月 22 日 & 5 品目 \\
4. & 平成 6 年 10 月 7 日 & 5 品目 \\
5. 平成 7 年 5 月 25 日 & 12 品目 \\
6. & 平成 7 年 10 月 25 日 & 23 品目 \\
7. & 平成 8 年 5 月 31 日 & 11 品目 \\
\hline & & 計 69 品目
\end{tabular}

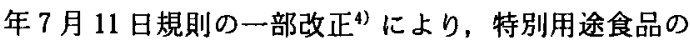
うち「食生活において特別の保健の目的で摄取する者に 対し，その摄取により当該保健の目的が期待できる旨の 標示するすの」を「特定保健用食品」とした (図 1 参照).

この制度が発足して平成 8 年で約 5 年が経過し, 許可 食品が出されてから 3 年が経過した。その間表 3 に示す ように年 2 回ずつ許可食品が公示され，特定保健用食品 の許可件数は, 平成 8 年 5 月 31 日現在で 69 品目となっ た.

その内訳を保健の用途でみると，表 4 に示すように腸 内細菌叢の改善に役立つものとしてオリゴ糖を利用した 6のが 40 品目之約 6 割を占めている. 次に多いのが非 便促進などを期待した食物緎維で7品目許可されてい る. 食物䄉維には，便秘予防（排便促進）を含方，肥満 予防，糖尿病予防，動脈硬化・胆石予防，有害物質の毒 性軽減，大腸ガン予防の 6 つの㗢きが一般に認められて (いる7) 9).なお, 食物織維は, 水溶性, 不溶性, 総食物織 維として成分值が公表されている

平成 7 年栄養改善法の一部が改正され，特殊栄養食品

表 4 特定保健用食品の許可内容による分類

(平成 8 年 5 月 31 日現在 69 品目)

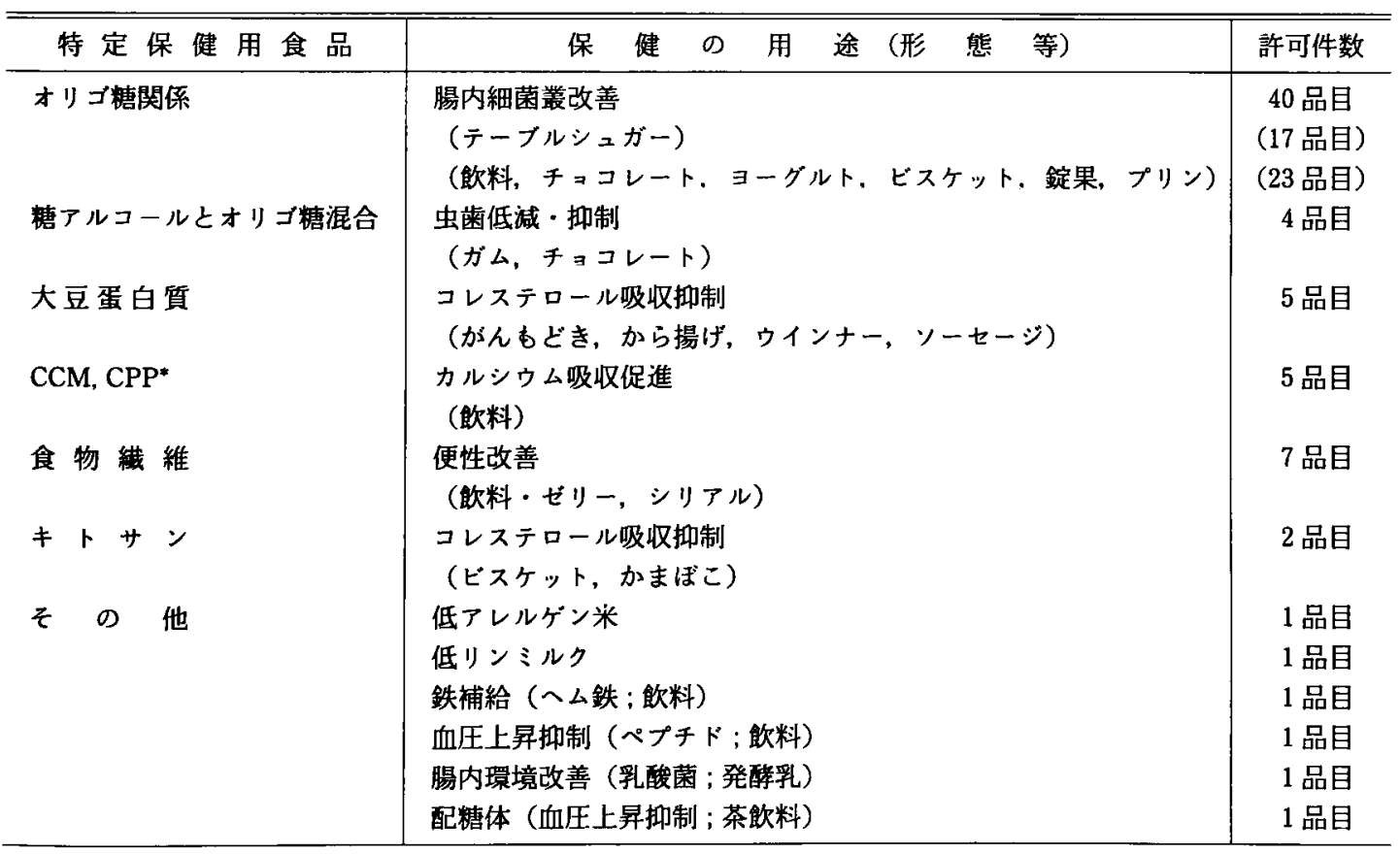

*CCM : クェン酸リンゴ酸カルシウム

$\mathrm{CPP}:$ カセインホスホペプチト 
の名称廃止, 強化食品制度が廃止されたが，特別用途食 品中の特定保健用食品の位置づけは变らないり（図 1 参 照).

\section{3. 栄養表示基準制度}

政府は，食品衛生法及び栄養改善法の一部を改正する
法律（平成 7 年法律第 101 号）において，「販売に供する 食品（特別用途食品を除く）について，厚生省令で定め る栄養成分又は熱量に関する表示をしょうとする者等 は，厚生大臣の定める栄養表示基準に従い必要な表示を 行うべきものとすること」とした1).

表示すべき項目は, 厚生省告示第 146 号 $^{11)}$ に示されて

表 5 補給ができる旨の表示について遵守すべき基準值一覧表

\begin{tabular}{|c|c|c|c|c|c|c|}
\hline \multirow[b]{2}{*}{ 栄養成分 } & \multicolumn{3}{|c|}{$\begin{array}{l}\text { (第 } 1 \text { 欄) 高い旨の表示をする場合は, いずれか } \\
\text { の基準值以上であること }\end{array}$} & \multicolumn{3}{|c|}{$\begin{array}{l}\text { 〔第 } 2 \text { 欄〕含む旨および強化された等旨の表示を } \\
\text { する場合は次のいずれかの基準値以上であること }\end{array}$} \\
\hline & $\begin{array}{l}\text { 食品 } 100 \mathrm{~g} \text { 当た } \\
(\text { ）内は, 清 } \\
\text { 食品 } 100 \mathrm{ml} \text { 当 }\end{array}$ & $\begin{array}{l}\text { 队料水等に供する } \\
\text { の場合 }\end{array}$ & $\begin{array}{l}100 \mathrm{kcal} \\
\text { 当たり }\end{array}$ & $\begin{array}{l}\text { 食品 } 100 \mathrm{~g} \text { 当た } \\
\text { （）内は, 清 } \\
\text { 品 } 100 \mathrm{ml} \text { 当た }\end{array}$ & $\begin{array}{l}\text { 次料水等に供する食 } \\
\text { 場合 }\end{array}$ & $\begin{array}{l}100 \mathrm{kcal} \\
\text { 当たり }\end{array}$ \\
\hline たんぱく質 & $14 \mathrm{~g}$ & $(7 \mathrm{~g})$ & $7 \mathrm{~g}$ & $7 \mathrm{~g}$ & $(3.5 \mathrm{~g})$ & $3.5 \mathrm{~g}$ \\
\hline 食物緎維 & $6 g$ & $(3 \mathrm{~g})$ & $3 g$ & $3 \mathrm{~g}$ & $(1.5 \mathrm{~g})$ & $1.5 \mathrm{~g}$ \\
\hline カルシウム & $180 \mathrm{mg}$ & (90 mg) & $60 \mathrm{mg}$ & $90 \mathrm{mg}$ & $(50 \mathrm{mg})$ & $30 \mathrm{mg}$ \\
\hline 鉄 & $3 \mathrm{mg}$ & $(1.5 \mathrm{mg})$ & $1 \mathrm{mg}$ & $1.5 \mathrm{mg}$ & $(0.8 \mathrm{mg})$ & $0.5 \mathrm{mg}$ \\
\hline ナイアシン & $5.1 \mathrm{mg}$ & $(2.6 \mathrm{mg})$ & $1.7 \mathrm{mg}$ & $2.6 \mathrm{mg}$ & $(1.3 \mathrm{mg})$ & $0.9 \mathrm{mg}$ \\
\hline ビタミンA & $600 \mathrm{IU}$ & $(300 \mathrm{IU})$ & $200 \mathrm{IU}$ & $300 \mathrm{IU}$ & (150 IU) & $100 \mathrm{IU}$ \\
\hline ビタミン $\mathrm{B}_{1}$ & $0.3 \mathrm{mg}$ & $(0.15 \mathrm{mg})$ & $0.1 \mathrm{mg}$ & $0.15 \mathrm{mg}$ & $(0.08 \mathrm{mg})$ & $0.05 \mathrm{mg}$ \\
\hline ビタミン $\mathrm{B}_{2}$ & $0.42 \mathrm{mg}$ & $(0.21 \mathrm{mg})$ & $0.14 \mathrm{mg}$ & $0.21 \mathrm{mg}$ & $(0.11 \mathrm{mg})$ & $0.07 \mathrm{mg}$ \\
\hline ビタミンC & $15 \mathrm{mg}$ & $(8 \mathrm{mg})$ & $5 \mathrm{mg}$ & $8 \mathrm{mg}$ & (4 mg) & $3 \mathrm{mg}$ \\
\hline ビタミン D & $30 \mathrm{IU}$ & (15 IU) & $10 \mathrm{IU}$ & $15 \mathrm{IU}$ & (8IU) & $5 \mathrm{IU}$ \\
\hline
\end{tabular}

表 6 適切な捸取ができる旨の表示について遵守すべき基準一覧表

\begin{tabular}{|c|c|c|c|}
\hline \multirow{2}{*}{ 栄養成分 } & $\begin{array}{l}\text { 〔第 } 1 \text { 欄 }] \\
\text { 含まない旨の表示は次の基準値に } \\
\text { 満たないこと }\end{array}$ & \multicolumn{2}{|c|}{$\begin{array}{l}\text { 〔第 } 2 \text { 欄〕 } \\
\text { 低い旨および低減された旨の表示は次の基準値以下である } \\
\text { こと }\end{array}$} \\
\hline & $\begin{array}{l}\text { 食品 } 100 \mathrm{~g} \text { 当たり } \\
\text { （飲用に供する食品にあっては } \\
100 \mathrm{~m} l \text { 当たり） }\end{array}$ & \multicolumn{2}{|l|}{ 食品 $100 \mathrm{~g}$ 当たり } \\
\hline 脂 & $0.5 \mathrm{~g}$ & $3 \mathrm{~g}$ & $(1.5 \mathrm{~g})$ \\
\hline 飽和脂肪酸 & $0.1 \mathrm{~g}$ & $\begin{array}{c}1.5 \mathrm{~g} \\
\text { かつ飽和脂肪酸由来エネル } \\
\text { ギーが全エネルギーの10\% }\end{array}$ & $\begin{array}{c}(0.75 \mathrm{~g}) \\
\text { かつ飽和脂肪酸由来エネル } \\
\text { ギーが全エネルギーの10\% }\end{array}$ \\
\hline 糖 & $0.5 \mathrm{~g}$ & $5 \mathrm{~g}$ & $(2.5 \mathrm{~g})$ \\
\hline ナトリウム & $5 \mathrm{mg}$ & $120 \mathrm{mg}$ & $(120 \mathrm{mg})$ \\
\hline 熱 & $5 \mathrm{kcal}$ & $40 \mathrm{Kcal}$ & $(20 \mathrm{Kcal})$ \\
\hline
\end{tabular}

（注）「ドレッシングタイプ調味料」について，脂質の項中「0.5 g」とあるのは，「3 g」とする. 
いるように, 当該食品 $100 \mathrm{~g}$ むしくは $100 \mathrm{~m} l$ 又は 1 食 分, 1 包装その他の 1 単位あたりの熱量, たんぱく質, 脂 質, 糖質,ナトリゥムならびに表示栄養成分の量となっ ている.これらの項目は，この順に記載することとなっ た.

高い旨の表示, 含む旨の表示および強化された旨の表 示については，表5に示すように，それぞれ表に掲げる 栄養成分の制給が出来る旨の表示として当該食品 $100 \mathrm{~g}$ あたり，清涼飲料水等にあっては $100 \mathrm{~m} l$ あたりの当該 栄養成分の量が示された。ここに言う高い旨とは，高， 多，豊富，增等の表示に，また，含む旨とは，源，供給 等の表示に相当するものと考えられる.

含まない旨，低い旨および低減された旨の表示につい ては、表 6 に掲げる栄養成分又は熱量の適切な攝取がで きる旨の表示として, 当該食品 $100 \mathrm{~g}$ あたり, 清涼飲料 水等にあっては $100 \mathrm{~m} l$ あたりの当該栄養成分の量又は 熱量が示された，含まない旨とは，無，ゼロ，ノン等の 表示に，また低い旨および低減された旨とは，低，軽， ひかえめ, 低隇，カット，オフ等の表示に相当するもの と考えられる。

紙面の都合により詳細な記載はできなかった，必要に 応じ，法律やその解説(2)13)をお読みいただきたい．

文献

1）大蔵省印刷局：官報第 1650 号, 食品衛生法及び
栄養改善法の一部を改正する法律（平成 7 年法律 第 101 号) (1995).

2）厚生省: 栄養改善法施行規則（昭和 27 年厚生省 令第 37 号）（1952）.

3）厚生省：特殊栄養食品の標示について（昭和 46 年衛発第 222 号) (1971).

4）厚生省: 栄養改善法施行規則の一部改正について (平成 3 年厚生省令第 41 号および平成 3 年衛新第 64 号) (1991).

5）厚生省：厚生白書, 昭和 62 年版 p.81 (1988).

6）荒井綜一監修: 機能性食品の研究，(学会出版七 ンター), p. 1 (1995).

7）地方衛生研究所全国協議会：食物織維成分表, (第一出版)， p. 79 (1990).

8）中村尚夫 : 治療, 75, 218 (1993).

9）中村尚夫 : 全栄協月報，No. 410，5 (1994).

10）科学技術庁資愿調查会：4言了版日本食品成分表の フォローアップに関する調查報告 $\mathrm{N}$, 日本食品食 物織維成分表 (1992).

11）大蔵省印刷局 : 官報号外第 119 号, 栄養表示基準 を定める件（平成 8 年厚生省告示第 146 号) (1996).

12）滝本浩司：農林水産技術研究ジャーナル，18（6), 30 (1996).

13）食品産業センター: 明日の食品産業, No. 266, 28 (1996).

（平成 8 年 10 月 8 日受理） 